IZA DP No. 6434

This Time It's Different?

Youth Labour Markets During 'The Great Recession'

Niall O'Higgins

March 2012 


\title{
This Time It's Different? Youth Labour Markets During 'The Great Recession'
}

\author{
Niall O'Higgins \\ LABESS \& CELPE, Università di Salerno \\ and IZA
}

Discussion Paper No. 6434

March 2012

\author{
IZA \\ P.O. Box 7240 \\ 53072 Bonn \\ Germany \\ Phone: +49-228-3894-0 \\ Fax: +49-228-3894-180 \\ E-mail: iza@iza.org
}

\begin{abstract}
Any opinions expressed here are those of the author(s) and not those of IZA. Research published in this series may include views on policy, but the institute itself takes no institutional policy positions.

The Institute for the Study of Labor (IZA) in Bonn is a local and virtual international research center and a place of communication between science, politics and business. IZA is an independent nonprofit organization supported by Deutsche Post Foundation. The center is associated with the University of Bonn and offers a stimulating research environment through its international network, workshops and conferences, data service, project support, research visits and doctoral program. IZA engages in (i) original and internationally competitive research in all fields of labor economics, (ii) development of policy concepts, and (iii) dissemination of research results and concepts to the interested public.
\end{abstract}

IZA Discussion Papers often represent preliminary work and are circulated to encourage discussion. Citation of such a paper should account for its provisional character. A revised version may be available directly from the author. 
IZA Discussion Paper No. 6434

March 2012

\section{ABSTRACT \\ This Time It's Different? \\ Youth Labour Markets During 'The Great Recession'”}

This paper looks at the effects of the 'Great Recession' on young people's labour market experiences in the European Union. The paper documents some of the key characteristics of young people's labour market experiences during the current recession and then seeks to provide some explanations of these applying both cross-section and time series rolling regression models in order, in particular, to better understand the role of labour market institutions as a determining factor of differing experiences across countries. The analysis finds that labour market flexibility contributed significantly to the negative consequences felt by young people during the recession.

JEL Classification: $\quad$ I28, J13, J23, J24

Keywords: recession, youth labour markets, human capital, EPL

Corresponding author:

Niall O'Higgins

DiSES

Università di Salerno

Via Ponte Don Melillo

84084 Fisciano (SA)

Italy

E-mail: nohiggins@unisa.it

\footnotetext{
* I would like to thank participants at conferences in Helsinki, Perugia and Vienna for their useful comments on previous drafts.
} 


\section{Introduction}

As of writing it remains unclear how long the present 'great recession' is likely to continue in EU countries. Apparent recovery has proved transitory in many countries and for some, Greece in particular, there is no sign of an imminent return to positive economic growth. This paper looks at the effects of the recession on young people's labour market experiences in the European Union. The next section documents some of the key characteristics of young people's labour market experiences during the current recession. Section 3 then seeks to provide some explanations of these, applying both cross-section and time-series rolling regression models in order, in particular, to better understand the role of labour market institutions as a determining factor of differing experiences across countries.

\section{Young people and the 'Great Recession' - A special case?}

\subsection{Youth unemployment}

Young people were undoubtedly hit hard by the recession albeit with much cross-country variation (Figure 1); youth unemployment rates in the EU as a whole rose by over 35 percent, or 5.5 percentage points, over the three year period between 2008Q3 and 2011Q3. A number of authors and international institutions have argued that young people were more severely affected by the recession than were other workers, basing this statement on an appeal to the percentage point change in unemployment rates of young people compared to adults. ${ }^{1}$

The emphasis on this justification for the affirmation is misplaced for at least three reasons: a) because, as is well known, youth unemployment rates are both significantly higher and more variable than prime age adult rates; b) due principally to participation in education, labour force participation rates are relatively low amongst young people, so that a substantial increase in youth unemployment rates may occur due to the unemployment of relatively few more young people; and

\footnotetext{
${ }^{1}$ See, for example, European Commission (2009), and Verick (2009).
} 
c) the longer term negative effects of extended unemployment are likely to be particularly severe for young people. ${ }^{2}$

Figure 1: Youth unemployment rates in EU countries, $2008 Q 3$ and 2011Q3

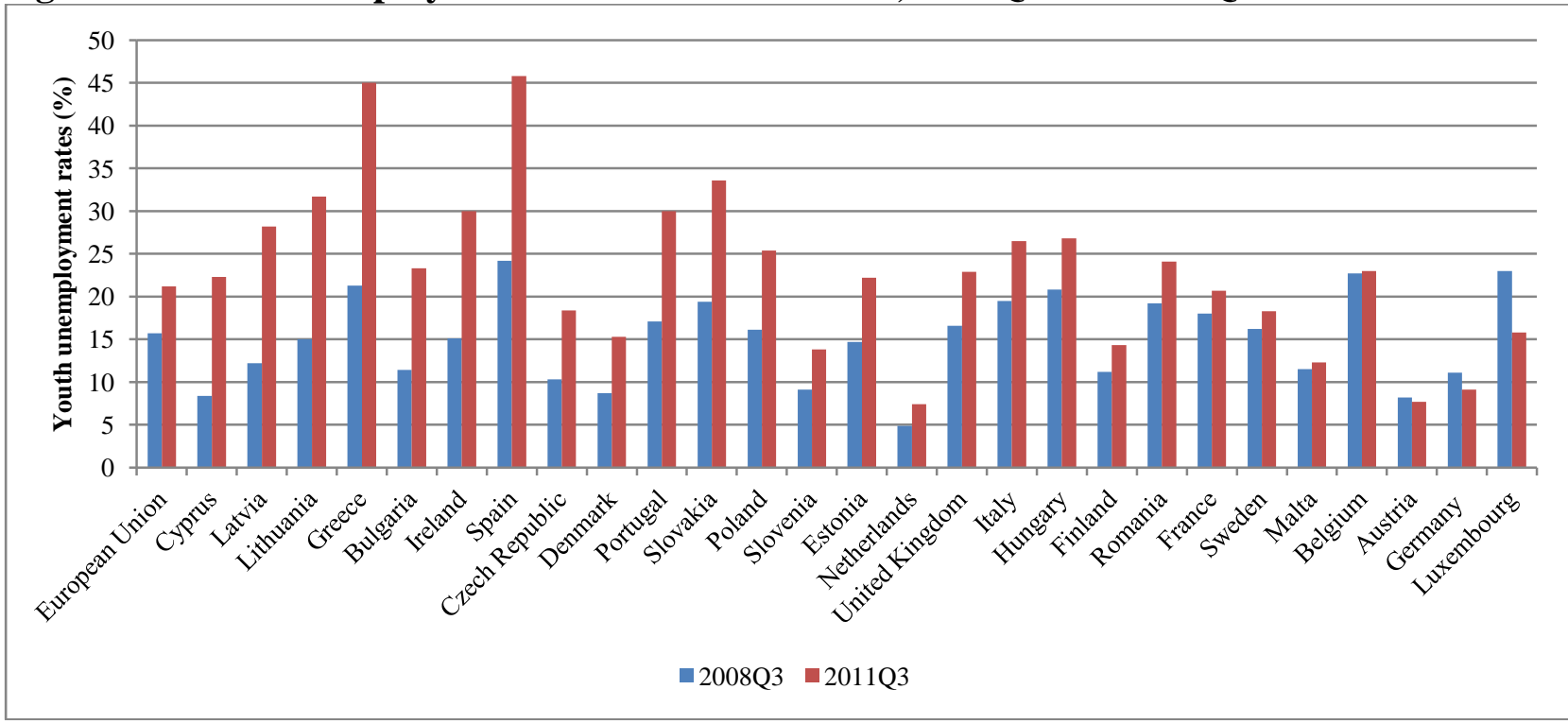

Source: Calculated from the Eurostat database, http://epp.eurostat.ec.europa.eu

Note: Countries are ordered from left to right in decreasing size of the percentage change in youth unemployment rates.

Point a) and point b) imply that a preferable way of looking at the relative impact of changes for different age-groups is by comparing changes in the unemployment rates of young people relative to another age-group; the obvious choice being prime-age adults. The overall EU situation (Figure 2) suggests that, although initially the youth-adult ratio of unemployment rates rose as the recession started to hit, this was actually a continuation of a longer term trend that was soon halted by the recession with the ratio rapidly falling after 2008. That is, the position of young people improved vis-à-vis adults during the recession at least in terms of relative unemployment rates. Again, there was considerable cross-country variation, and for young people in seven countries,

\footnotetext{
${ }^{2}$ See, for example, O'Higgins $(1997,2001)$ on the relationship between youth and adult unemployment rates. On the extent to which young people were affected by the current recession see also, European Commission (2010) which contains a rather more articulated discussion of the effects of the recession on different groups than was contained in the previous year's publication. The report notes inter alia that, splitting the labour force into ten year age-groups, the largest slice of the increase in unemployment between 2008 and 2010, 30\%, was accounted for by increased unemployment amongst 25-34 year olds, nearly one quarter (23.5\%) by 35-44 year olds and only $18 \%$ was accounted for by increased unemployment amongst young people - the same proportion accounted for by older adults (aged 4554). So that only those aged 55 and over contributed less than young people to the increase in unemployment.
} 
comprised of New Member States (NMS), Italy and Portugal, the relative situation of young people worsened considerably (Figure 3). In most countries, however, the relative position of young people, as measured by this ratio, improved and in some countries quite considerably.

Figure 2: Ratio of youth to adult unemployment rates, EU 1987-2010

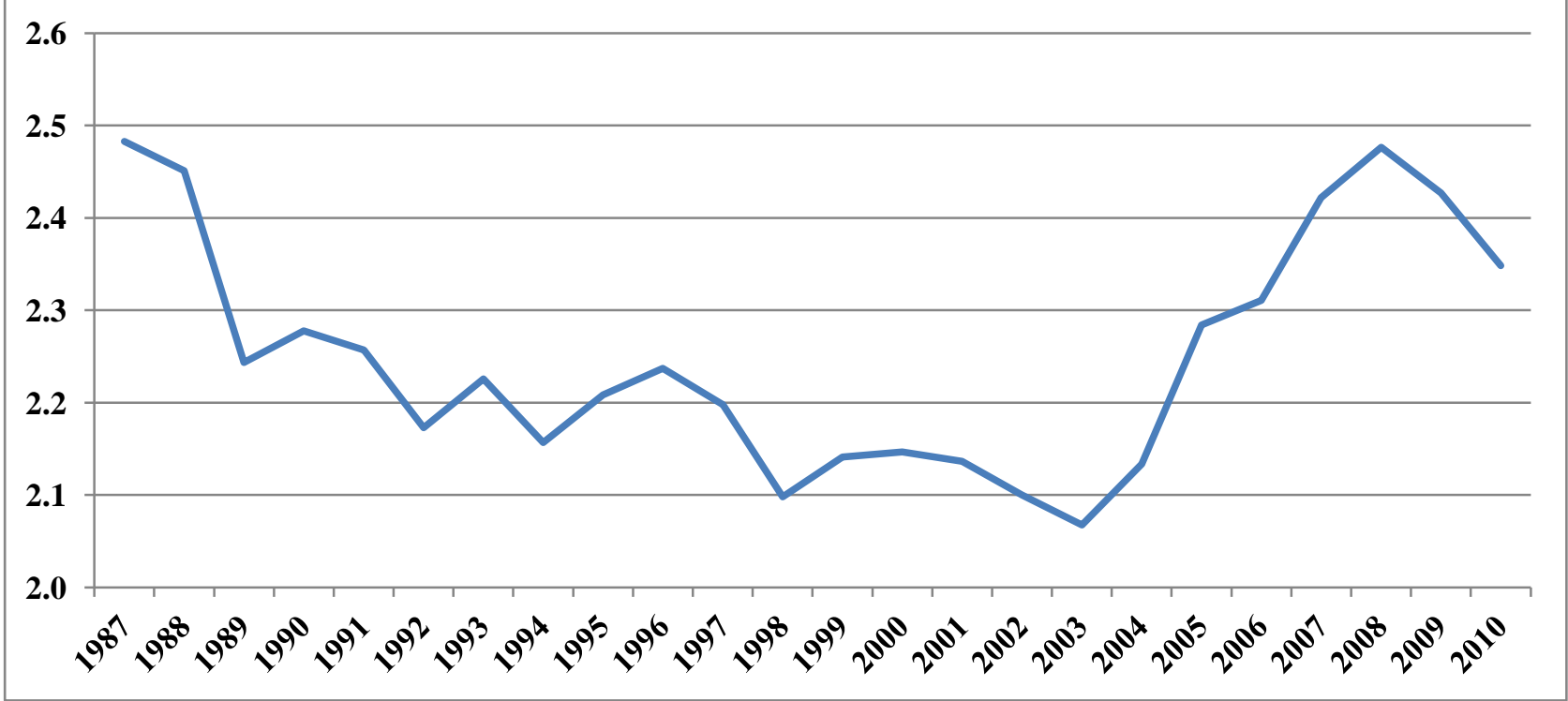

Source: Calculated from the Eurostat database, http://epp.eurostat.ec.europa.eu

Note: the figure reports the ratio of annual youth (15-24) unemployment rates to prime-age (25-49) adult rates, 19872010.

Figure 3: Change in the ratio of youth to adult unemployment rates by country, EU $2008 Q 3$ $2011 Q 3$

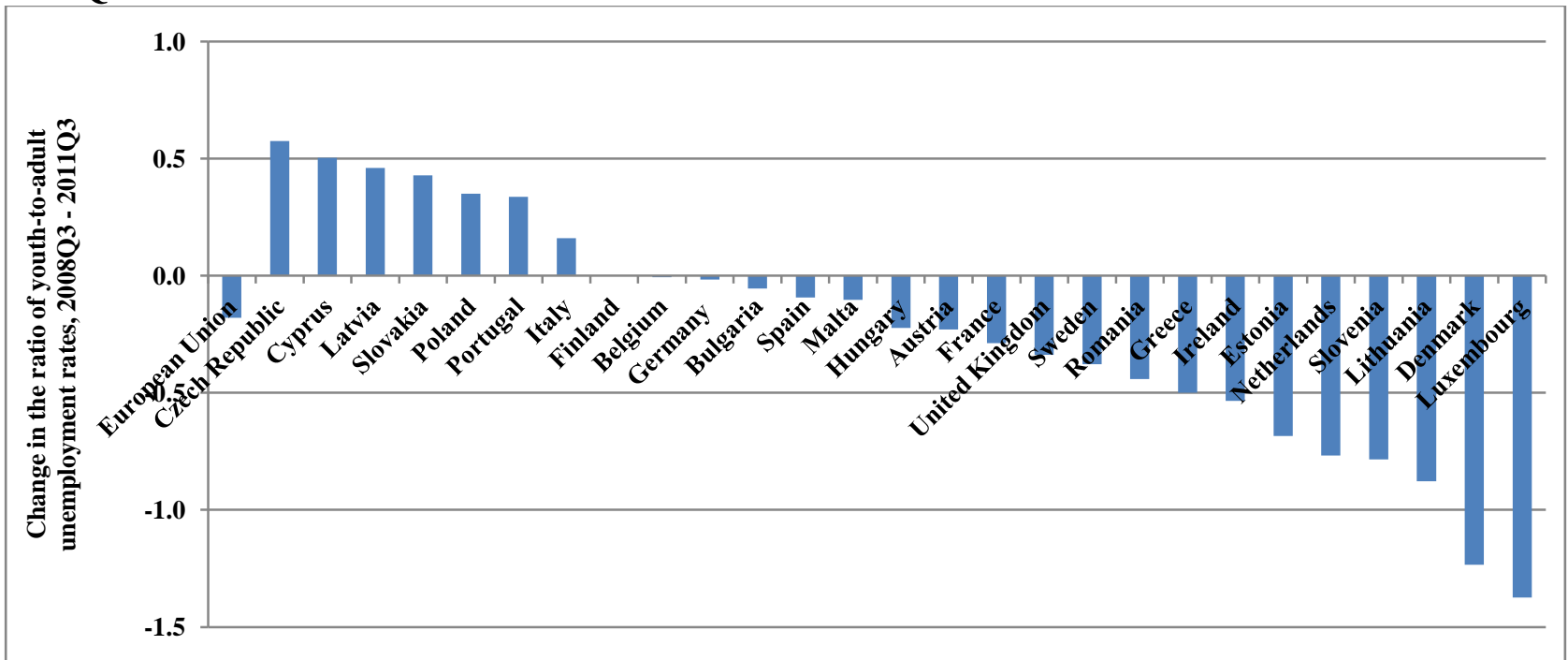

Source: Calculated from the Eurostat database, http://epp.eurostat.ec.europa.eu

Notes: 1) The figure reports the absolute change in the ratio of annual youth (15-24) unemployment rates to prime-age (25-49) adult rates over the period 2007Q3 - 2010Q3.

2) Countries are ordered from left to right in decreasing size of the change in the ratio. 


\subsection{Long-term youth unemployment}

A number of papers over the years have noted that the effects of unemployment and/or joblessness early on in one's 'working' career are likely to have long-term effects on employment prospects and wages (e.g. Gregg, 2001, and Gregg and Tominey, 2005). ${ }^{3}$ Methodological difficulties with separating individual heterogeneity from 'true' duration dependence cast some doubt on the causal influence of early unemployment on later careers identified by early studies. However, the regularity with which such scarring has been found, at least in the European context, as well as more recent attempts to control for these selectivity effects suggest that there really is a scarring effect that goes beyond unobserved individual heterogeneity (e.g. Cockx and Picchio, 2011). The implication is that extended difficulties in the search for work early on are likely to have long-term negative consequences. ${ }^{4}$ In the context of the current prolonged recession, this creates the spectre of a lost generation of young people who become permanently excluded from productive employment (Scarpetta et al., 2010). From this point of view, it is not so much that more young people than adults were affected by the current recession because this is debatable and depends a little on how 'more' is defined as well as where one happens to live, - but rather that young people were more affected by the recession than adults in terms of the long-run consequences.

Changes in the incidence of long-term unemployment will tend to reflect the effects of the recession on outflows from, and inflows to, unemployment. Long-term unemployment will tend to increase if new entrants to unemployment outnumber exits from it. Consequently one would expect that the initial effects of a recession would be to reduce long-term unemployment due to the large numbers of new entrants to unemployment; in the case of young people, many of these will be new labour market entrants who initially fail in their search for work. As the recession draws out, longterm unemployment may well rise as the unemployed find it increasingly difficult to find work and who will be further hampered by the fact that they have been unemployed for a significant period

\footnotetext{
3 The cited paper provides perhaps the strongest case for duration dependence, looking at the effects of early unemployment on career prospects some ten-fifteen years later, controlling for observed heterogeneity.

${ }^{4}$ Gregg \& Tominey (2005) identify a scarring effect on wages more than twenty years after unemployment episodes experienced during youth.
} 
of time. ${ }^{5}$ This is the spectre of the lost generation identified by the OECD paper cited above. Figure 4 illustrates that this has indeed been occurring in the EU. As youth unemployment began to rise, after an initial slight reduction, the incidence of long-term unemployment amongst the young unemployed increased rapidly, and has continued to do so even as, in the last year or so, youth unemployment rates have reached a plateau. The rise appears to have been steepest in Spain and Ireland, two of the countries that were hardest hit by the recession (Figure 5). ${ }^{6}$

Figure 4: Youth unemployment rates and the incidence of youth long-term unemployment, EU 2005Q1 - 2011Q3

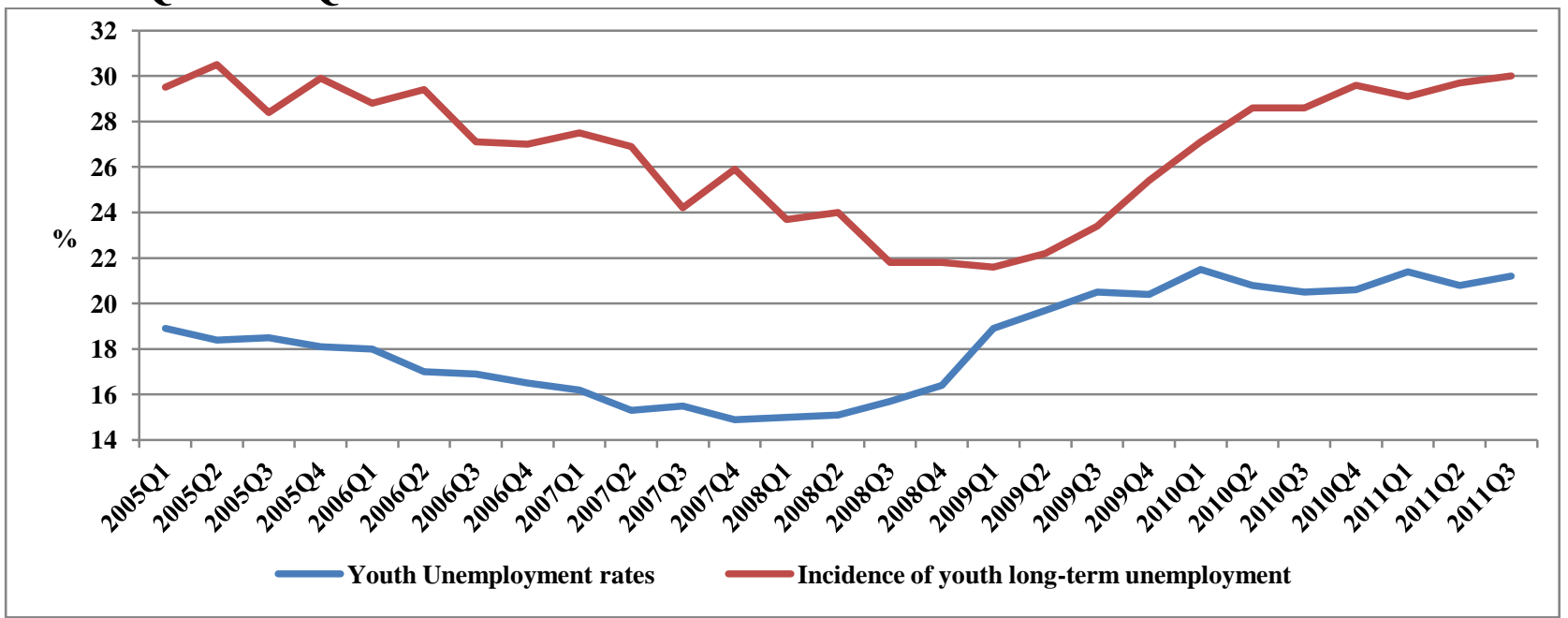

Source: Eurostat database, http://epp.eurostat.ec.europa.eu

Note: The youth unemployment rate is expressed as a percentage of the youth labour force, while the incidence of youth long-term unemployment is defined as the percentage of unemployed young people who have been in that state for more than one year.

To some extent the change appears to bear an inverse relation to the pre-crisis incidence of longterm unemployment, but the correlation is weak $(-0.25)$ and in some countries, most notably Italy, young people suffered from both a substantial pre-crisis incidence and a significant increase in the incidence of unemployment in the interim. Perhaps of most importance, between the third quarters

\footnotetext{
${ }^{5}$ However, this effect may of course be attenuated by the introduction of Active Labour Market Policies (ALMP) targeting the long-term unemployed.

${ }^{6}$ Unfortunately data is not available on the incidence of long-term unemployment over this period for any of the Baltic countries, all three of whom were also very hard hit by the recession. As yet, young people in Greece do not seem to have been so severely affected, however, since the recession started to bite rather later in that country, it is predictable that the incidence will rise here too in the near future.
} 
of 2008 and 2011the rate of increase in the incidence of long-term unemployment has been much faster amongst young people than among prime-age adults (aged 25-49) so that the mean incidence of long term unemployment amongst young people, expressed as a percentage of the prime-age adult incidence of long-term unemployment, increased by ten percentage points over the period from $58 \%$ to $68 \%$, despite numerous interventions during the crisis to ameliorate the effects of the recession on youth labour markets. ${ }^{7}$ This is an issue that should be of central concern to policymakers.

Figure 5: Incidence of long-term unemployment amongst young people in $2008 \mathrm{Q3}$ and the percentage point change in incidence $2008 \mathrm{Q}-2011 \mathrm{Q} 3$

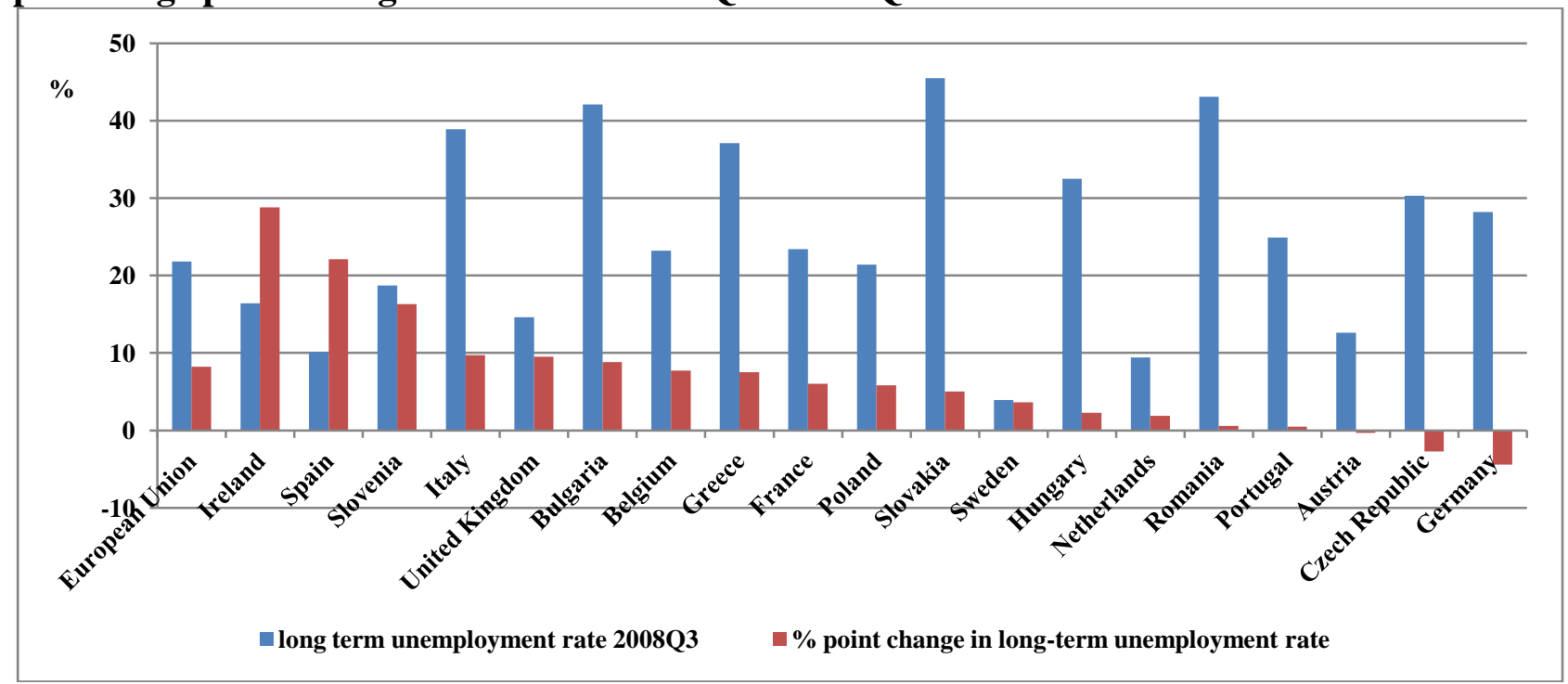

Source: Calculated from the Eurostat database, http://epp.eurostat.ec.europa.eu

Note: The incidence of youth long-term unemployment is defined as the percentage of unemployed young people who have been in that state for more than one year.

\subsection{Temporary employment}

The growing incidence of temporary employment amongst young people is a common aspect of youth labour markets in the EU. By the third quarter of 2008, the incidence of temporary employment amongst employees as a whole was $14.4 \%$, whilst for young people the incidence had reached $41.8 \%$; two out of every five young employees in the EU were in temporary employment. During the recession the incidence rose to $44.3 \%$ (in 2011Q3) so that in many countries practically

\footnotetext{
${ }^{7}$ See, for example, O'Higgins (2010) for a more detailed discussion of the Active Labour Market Policies - and their efficacy - introduced during the current recession.
} 
all new employment opportunities arising since the recession began have been temporary. ${ }^{8}$ The significance of this phenomenon will be discussed below.

\section{Towards explaining the effects the recession on youth labour markets and how these differed across countries}

A number of recent and some not so recent papers have looked at the factors driving youth employment and unemployment, in recent years focusing on the role of labour market institutions. Throughout this literature, from its beginnings in the 1980s, studies have unanimously found a major role for aggregate demand in determining youth labour market outcomes with a more variable role played by demographic and, above all, institutional factors. ${ }^{9}$ Jimeno and Rodriguez-Palenzuela (2002) and Bertola et al. (2007) find a role for unionization rates in reducing youth employment; the former attribute this to wage compression, whilst the latter argue rather more convincingly that unions bargain to protect their core members, prime age males, and are more willing to accept employment losses amongst more peripheral groups such as young people and women. Neither study finds a significant role for Employment Protection Legislation (EPL) per se. The comprehensive study of the role of institutions on employment patterns undertaken by Bassanini and Duval (2006), on the other hand, find a role for EPL in depressing youth employment rates, but, in contrast to Jimeno and Rodriguez-Palenzuela (2002), they also find a positive impact of youth minimum wages on youth employment.

In the context of the current recession, a number of papers have started to look at the role of recessions, as opposed to fluctuations in aggregate demand per se, in determining aggregate and/or youth labour market outcomes. Choudhry et al. (2012) find a consistently positive impact of financial crises on youth unemployment over and above that attributable to variations in aggregate demand whilst Bernal-Verdugo et al. (2012) find inter alia that more flexible labour markets tend

\footnotetext{
${ }^{8}$ This was the case in Italy, for example - for both younger and older workers - although of course the phenomenon was much more pronounced amongst the young (O’Higgins, 2011). For the working population as a whole, the incidence of temporary employment remained constant over the period at $14.4 \%$.

${ }^{9}$ Early examples here are Clark \& Summers (1982) on the USA and Rice (1986) on the UK.
} 
to exacerbate the initial negative employment effects of financial crises but that the negative effects of crises last longer in countries with more protected labour markets, particularly so in the case of youth labour markets.

\subsection{Cross-section analysis}

In the light of these findings based on analyses of previous crises, I look here at the effects of the present crisis on youth labour markets with the aim of identifying factors underlying crosscountry differences. A cursory look at the data suffices to establish that youth labour market outcomes were not simply the result of the severity of the crisis (Figure 6). The fall in real GDP is clearly positively associated with the fall in youth employment, but the fit is not very strong with an $\mathrm{R}^{2}$ value of less than 0.2 and there are numerous outliers.

\section{Figure 6: The depth of the recession and the percentage change in youth employment}

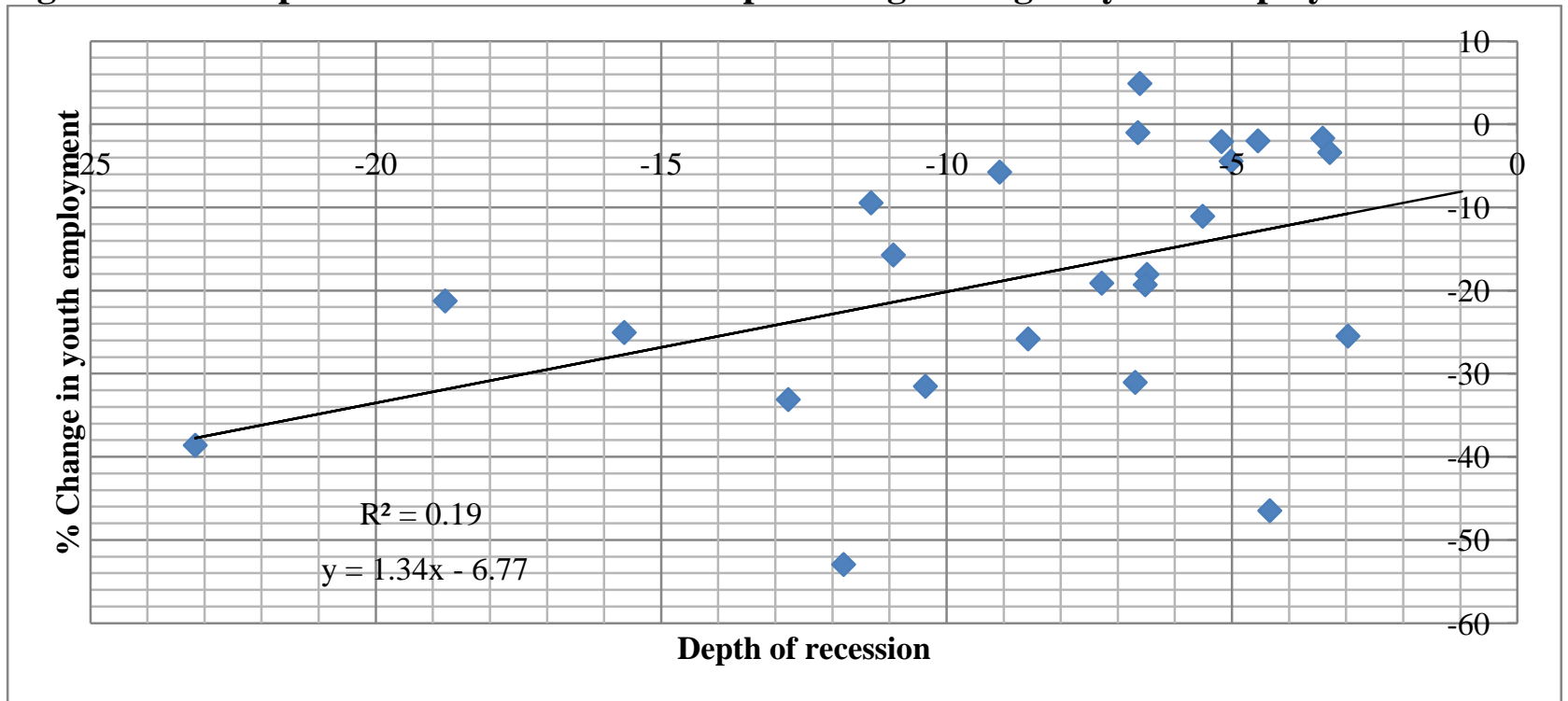

Source: Calculated from the Eurostat database, http://epp.eurostat.ec.europa.eu

Note: The depth of the recession is defined here as the difference between the maximum and minimum values of real GDP over the period 2007Q1 and 2010Q4 using a four quarter moving average. The percentage change in youth employment is measured over the period, 2007Q1 and 2011Q1.

A simple econometric framework serves to illuminate the changes in youth labour markets during the current recession. A cross-section model is used to characterise the associations between youth labour market indicators and the economic and institutional characteristics of European 
Table 1: OLS regressions on changes in youth labour market indicators over the period 2007Q1 - 2011Q1

\begin{tabular}{|c|c|c|c|c|c|c|c|c|c|c|}
\hline & \multicolumn{10}{|c|}{ Dependent variables } \\
\hline & \multicolumn{4}{|c|}{$\begin{array}{l}\% \text { point change in the Emp/Pop } \\
\text { ratio 2007Q1 - 2011Q1 }\end{array}$} & \multirow{2}{*}{\multicolumn{2}{|c|}{$\begin{array}{l}\text { \% point change in the } \\
\text { OLF/Pop ratio } \\
\text { 2007Q1 - 2011Q1 } \\
\text { Males \& Females }\end{array}$}} & \multirow{2}{*}{\multicolumn{2}{|c|}{$\begin{array}{c}\text { \% point change in } \\
\text { the Unemp/Pop } \\
\text { ratio } 2007 Q 1 \text { - } \\
2011 Q 1 \\
\text { Males \& Females }\end{array}$}} & \multirow{2}{*}{\multicolumn{2}{|c|}{$\begin{array}{c}\% \text { point change in } \\
\text { the incidence of LT } \\
\text { Unemp 2007Q1 - } \\
2011 Q 1 \\
\text { Males \& Females }\end{array}$}} \\
\hline & \multicolumn{2}{|c|}{ Males \& Females } & \multicolumn{2}{|c|}{ Males } & & & & & & \\
\hline & Coeff & S.E. & Coeff & S.E. & Coeff & S.E. & Coeff & S.E. & Coeff & S.E. \\
\hline Explanatory variables & & & & & & & & & & \\
\hline Depth of recession & -0.48 & 0.29 & -0.73 & 0.37 & 0.23 & 0.18 & 0.25 & 0.15 & 1.36 & 0.68 \\
\hline EPL Index (aggregate) & 2.55 & 2.16 & 2.29 & 2.71 & -2.34 & 1.34 & -0.22 & 1.07 & 0.49 & 4.15 \\
\hline $\begin{array}{l}15-24 \text { year olds, Emp/pop ratio } \\
2007\end{array}$ & -0.27 & 0.14 & -0.36 & 0.18 & 0.20 & 0.09 & 0.08 & 0.07 & 0.40 & 0.26 \\
\hline $\begin{array}{l}15 \text { - } 64 \text { year olds emp/pop ratio } \\
2007\end{array}$ & 0.29 & 0.26 & 0.34 & 0.32 & -0.22 & 0.16 & -0.07 & 0.13 & 0.08 & 0.53 \\
\hline $\begin{array}{l}\text { Youth as } \% \text { of working age } \\
\text { population }\end{array}$ & 0.94 & 0.60 & 1.29 & 0.75 & -0.60 & 0.37 & -0.34 & 0.30 & -0.77 & 1.10 \\
\hline Dual & 7.73 & 3.32 & 9.73 & 4.16 & -4.87 & 2.05 & -2.87 & 1.65 & -9.74 & 6.03 \\
\hline Intercept & -35.66 & 23.59 & -41.59 & 29.55 & 25.94 & 14.58 & 9.81 & 11.73 & -11.36 & 52.11 \\
\hline Adjusted R-squared & & & 0.2 & & & & 0.06 & & & \\
\hline $\mathrm{n}$ & & & 2 & & & & 25 & & & \\
\hline
\end{tabular}

Source: Estimated on data extracted from the Eurostat database (http://epp.eurostat.ec.europa.eu/). The OECD EPL index is taken from the OECD's website (www.oecd.org). Notes: 1) The explanatory variables are explained in the text.

2) The dependent variables are the percentage point change over the period 2007Q1 - 2011Q1 in a) the youth employment rate, b) the percentage of young people who are out-of-the-labour force; c) the young unemployed expressed as a percentage of the youth population; and d) the percentage of young people who have been unemployed for over one year.

3) Statistical significance is indicated by coefficients reported in bold $(\mathrm{p}<.05)$ or italics $(\mathrm{p}<.10)$. 
countries over the period (Table 1). The Table reproduces the results of regressing the percentage point changes in the major youth labour market indicators, the youth employment-population ratio, the youth labour force (non-) participation rate, the youth unemployment-population ratio and the incidence of long-term unemployment amongst young people, over the period 2007Q1 - 2011Q1, on a small set of variables representing the depth of the recession, cohort crowding, and variables intended to capture institutional features of the labour market. Specifically, the depth of the recession variable is based on a four period moving average of a quarterly index of not seasonally adjusted real GDP $(2000=100)$; the depth of the recession is defined as the difference between the high and low points of the series (for each country) between 2007Q1 and 2011Q1 thus measured. The other explanatory factors included are the OECD's EPL index for 2008, the youth and total working age employment rates in the first quarter of 2007, the percentage of young people in the working age population intended to capture cohort crowding, and a dummy variable capturing the countries in the sample which operate a dual apprenticeship system. ${ }^{10}$

The model is best thought of as descriptive rather than explanatory, however, the results are I believe both interesting and informative. Taking the results as whole, one may observe that the signs of coefficients are internally consistent; variables that are positively associated with employment changes are negatively associated with labour market exit and unemployment. With the exception of the employment-population ratio regression, for which results are also reported for young males, the Table reports estimates for males and females together. The employmentpopulation ratio estimation is typical of the gender separated results in that the effects of independent variables are generally stronger for males taken on their own, and is included mainly for illustrative purposes. The statistical significance of individual coefficients tends to be rather weak, however, this is not at all surprising given that this is a cross-section model with only 25 observations. Indeed, with the exception of the unemployment regression, which is singularly

\footnotetext{
${ }^{10}$ With the exception of the OECD's EPL index and the dual apprenticeship dummy, all the variables, explanatory and dependent, are derived from the Eurostat database (http://epp.eurostat.ec.europa.eu/). The OECD index is available form the OECD's website (www.oecd.org).
} 
statistically insignificant, the overall fit with R-squared values in the range $0.24-0.31$ is surprisingly good in the circumstances.

As one would expect, the depth of the recession is negatively associated with changes in the youth employment-population ratio and positively with labour market exit as measured by the change in the out-of-the-labour-force/population ratio and the unemployment/population ratio, as well as contributing to increases in the incidence of long-term unemployment as was suggested in the purely graphical analysis reported above. The associations are statistically significant (at $\mathrm{p}<$ .10) in the case of male employment, unemployment and long-term unemployment incidence, however, the depth of the recession was neither the only nor perhaps even the key determinant of such movements.

Interestingly, the strength of employment protection seems to have had an, albeit weak, beneficent influence. The OECD's strength of EPL index is positively related to the change in employment and, even more important, negatively to labour market withdrawal and unemployment. This suggests that, in countries where EPL is strong, young people were less likely to become discouraged workers or unemployed. The general lack of statistical significance suggests caution here, yet the consistency of the sign is suggestive. Certainly, it does not support the idea that young people were additionally disadvantaged in countries with strong employment protection legislation.

The pre-recession employment-population ratio of 15-24 year olds is negatively related to changes in the youth employment-population ratio and positively to the other indicators. This in part depends on the ratio picking up educational participation. That is, youth employment fell less in countries with a larger secondary and tertiary educational participation rates. The overall employment rate, introduced as a control for the pre-recession state of the aggregate labour market, is positively related to changes in youth employment and, with the exception of long-term unemployment, negatively with the other indicators although in all cases the coefficients on this variable are not statistically significant. 
Curiously, the relative size of the youth population is positively associated with employment changes and negatively with labour market withdrawal. This is not supportive of the cohort crowding hypothesis à la Korenman and Neumark (2000) and, indeed, is more in line with the findings of Shimer (2001) for the USA.

Finally, in order to partially control for country fixed effects, a dummy indicator was introduced for the four countries, Austria, Denmark, Germany and Switzerland, operating a dual apprenticeship system. ${ }^{11}$ This variable is consistently statistically significant, and, as one might expect, is strongly associated with labour market success in terms of the maintenance of both employment and labour market attachment.

Taken as a whole, these results do not support the notion of larger negative effects of the recession in countries with stronger employment protection and more generally stronger institutional bases. The protected entry systems offered by the dual apprenticeship system seem to have been particularly effective in shielding young workers from the effects of the recession.

\subsection{Time series analysis: rolling regressions}

It is possible to take the discussion farther by analysing changes over time in the relationship between key variables. By adopting a rolling regression approach one can look at the stability of the short-run relationship between economic growth and youth labour market indicators in what is essentially an Okun Law inspired environment. In recent years, much has been made of the interaction of economic and policy variables in determining labour market outcomes, and analysis of the stability of the economic growth-employment allows us to throw additional light on what has been happening during the current recession. ${ }^{12}$

Specifically, equations of the form:

\footnotetext{
${ }^{11}$ Obviously, being a cross-section regression, a full set of country fixed effects would not be identified.

${ }^{12}$ Indeed, much of the aforementioned Bassanini \& Duval (2006) paper is taken up with a consideration of such interactions. For a recent treatment, see also, Sachs (2011).
} 


$$
\operatorname{Ln}\left(E R_{i t}^{y}\right)=\alpha_{i}+\beta_{i} \operatorname{Ln}\left(G D P_{i t}\right)+\varepsilon_{i t}
$$

where $E R_{i t}^{y}$ is the youth employment rate for country $\mathrm{i}$ at time $\mathrm{t}$ and $G D P_{i t}$ is an index of real GDP also for country i at time t, were estimated with rolling regressions for each EU country on quarterly data over 20 quarters from 1998Q1 until 2011Q4. ${ }^{13}$ The approach is similar in spirit to that adopted by the IMF (2010) and Cazes et al. (2011) although the key 'dependent' variable used here is the employment rate rather than the unemployment rate.

It is informative to split the relation into two parts; the reactivity of prime-age (25-49) adult employment to variations in real GDP, and the relationship between youth and adult employment rates, so that we also estimate two further equations:

$\operatorname{Ln}\left(E R_{i t}^{a}\right)=\alpha_{i}+\beta_{i} \operatorname{Ln}\left(G D P_{i t}\right)+\varepsilon_{i t}$

and

$\operatorname{Ln}\left(E R_{i t}^{y}\right)=\alpha_{i}+\beta_{i} \operatorname{Ln}\left(E R_{i t}^{a}\right)+\varepsilon_{i t}$

Where $E R_{i t}^{a}$ is the prime-aged adult (25-49) employment rate for country i at time t. ${ }^{14}$

Figure 7 illustrates the time trend in the mean value of the beta coefficients produced by estimating the three equations. One can observe that overall the elasticity of the youth employment rate with respect to GDP has risen over the period; from .06 in the first five year slice to .70 in the final period covering the recession in its entirety (so far). One can also observe from the Figure that the increase is largely driven by the increasing reactivity of youth employment to adult employment, which almost doubled over the period from 1.69 to 3.28 , rather than by any substantial

\footnotetext{
${ }^{13}$ The employment rate is preferred to the unemployment rate, since it is more indicative of demand side changes in the youth labour market. For a discussion of this issue in this context, see, for example, O'Higgins (2010).

${ }^{14}$ This of course ignores what was going on with older workers. Many of the countries have been, and many still are, undergoing reform of their pension systems which has often created countercyclical movements in employment rates amongst older workers (see, for example, O’Higgins, 2010). For this reason, they are excluded here.
} 
rise in the elasticity of the adult employment rate with respect to GDP which did also increase although the change was much more moderate, from 0.16 to 0.24 .

Figure 7: Beta values for rolling regressions (1) - (3)

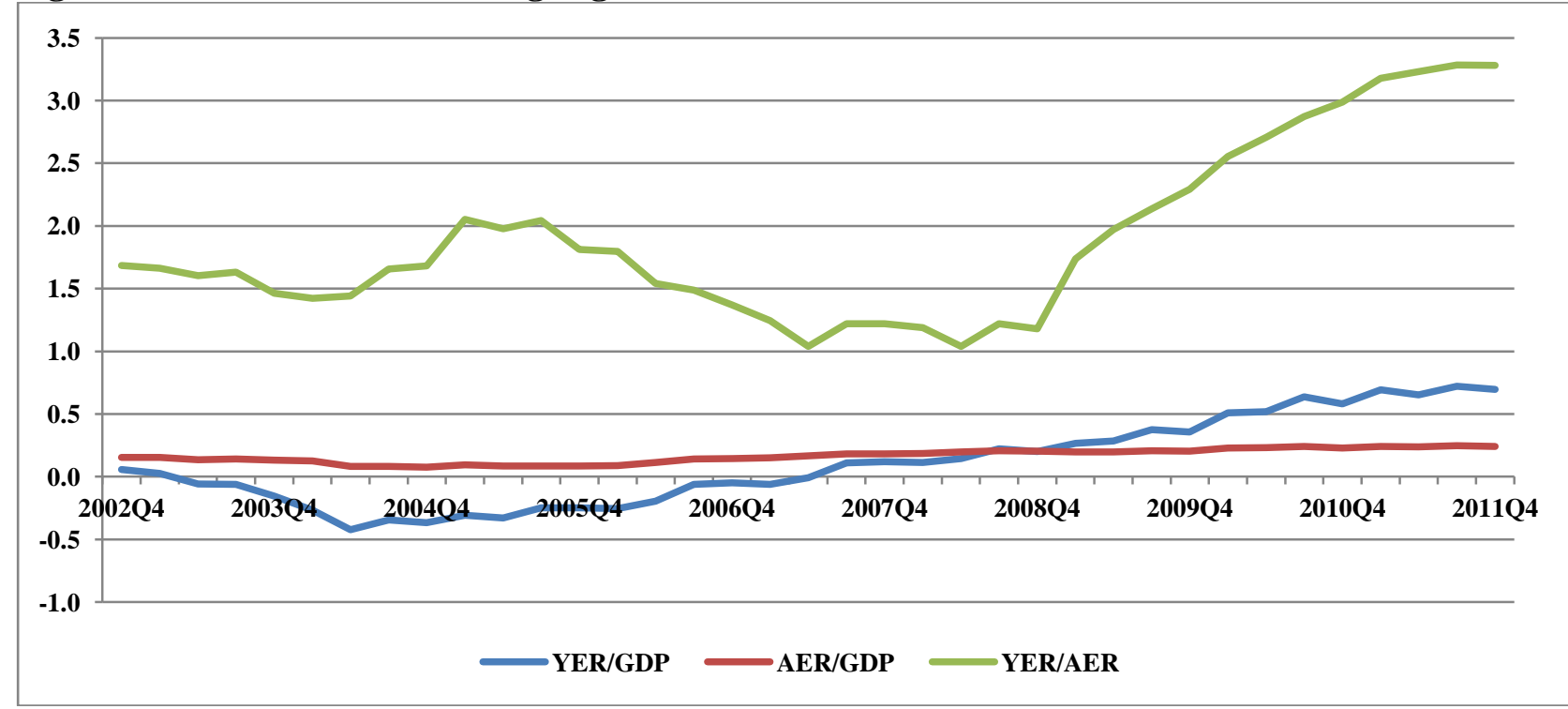

Source: Calculated from the Eurostat database, http://epp.eurostat.ec.europa.eu

Notes: 1) The figure reports the beta values from estimates of rolling regressions on equations (1) - (3) in the text; specifically, YER/GDP is the elasticity of the youth employment rate to real GDP, AER/GDP is the elasticity of the adult employment rate to GDP and YER/AER is the elasticity of the youth employment rate to the adult rate.

2) reported dates on the $\mathrm{X}$-axis are the last quarter of the 20 quarter estimation period.

Concentrating on the youth-adult employment rate relation, Table 2 reports, in order of the size of the elasticity, the elasticity of youth employment rates to the adult rate at the end of the period under consideration for each country. ${ }^{15}$ The Table also reports the OECD's Employment Protection index (version 1) for temporary employment as well as the year of any recent reduction in the index. ${ }^{16}$ One can immediately observe that out of the nine countries with an youth-adult employment elasticity of more than four, all but two, Italy and Spain, are characterised by the fact that they either have very little regulation of temporary contracts (with the OECD index $<1$ ) or have recently relaxed the legislation on temporary contracts or both. The exceptions, Italy and Spain, are both characterised by the widespread introduction of temporary contracts in recent years, indeed, as was noted above, since the recession began almost all new hires in Italy are on the basis

\footnotetext{
${ }^{15}$ Specifically, it reports the mean value of the youth-adult employment elasticity beta coefficient for the last four rolling regressions.

${ }^{16}$ Version 1 is used because of the use of time series observations on this index.
} 
Table 2: Elasticity of the youth employment rate to the adult employment rate, 2007Q4 2011Q4

\begin{tabular}{|l|c|c|c|}
\hline & $\begin{array}{c}\text { End period youth-adult } \\
\text { employment elasticity }\end{array}$ & $\begin{array}{c}\text { OECD EPL Index - } \\
\text { temporary employment } \\
\text { (2008) }\end{array}$ & $\begin{array}{c}\text { Reduction in } \\
\text { OECD index } \\
\text { since 2007 (year) }\end{array}$ \\
\hline Finland & 6.63 & 1.75 & 2008 \\
\hline Sweden & 5.87 & 0.88 & 2007 \\
\hline Portugal & 5.67 & 2.13 & 2007 \\
\hline United Kingdom & 5.52 & 0.38 & \\
\hline Italy & 5.09 & 2.00 & \\
\hline Spain & 5.07 & 0.88 & \\
\hline Slovakia & 4.39 & 3.50 & \\
\hline Ireland & 4.19 & 0.38 & \\
\hline Greece & 4.14 & 0.63 & \\
\hline Hungary & 3.83 & 3.13 & \\
\hline Slovenia & 3.79 & 1.38 & \\
\hline Latvia & 3.22 & 2.98 & \\
\hline Netherlands & 3.09 & n.a. & \\
\hline Romania & 2.92 & 1.19 & \\
\hline Bulgaria & 2.78 & n.a. & \\
\hline Lithuania & 2.67 & n.a. & \\
\hline Denmark & 2.63 & n.a. & \\
\hline Estonia & 2.24 & 1.38 & \\
\hline France & 2.23 & n.a. & \\
\hline Austria & 2.21 & $3.25(2009)$ & \\
\hline Poland & 1.90 & 1.50 & \\
\hline Belgium & 1.84 & 1.75 & \\
\hline Germany & 1.79 & 1.25 & \\
\hline Sorce: & 1.59 & 2009 & \\
\hline
\end{tabular}

Source: The first column of the table is based on the estimates produced by the rolling regressions applied to equation (3); the second and third columns are based on the OECD database (www.OECD.org

Notes: 1) The first column of the table reports the mean estimated elasticity for the last four periods of the rolling regressions covering the period 2007Q4 - 2011Q4.

2) The OECD EPL index employed is version 1 to allow comparison over time. See the OECD website for details.

if temporary contracts (O’Higgins, 2011). ${ }^{17}$ At the other end of the spectrum, one observes Austria, Denmark and, right at the bottom, Germany, three countries characterised by their moderate

\footnotetext{
${ }^{17}$ Both Italy and Spain are also characterised by the so-called 'Mediterranean Labour Market Model' which has to do with the role of family, as opposed to the State, as the guarantor of the income of family members other than the principal (usually male) breadwinner. This has a number of implications which go beyond the scope of the current paper, but which include the greater difficulty of young Mediterraneans in accessing full-time permanent jobs. See, for
} 
regulation of temporary contracts and, above-all, their use of a dual apprenticeship system in facilitating the school-to-work transition.

It might be argued, indeed, it not infrequently is argued, that flexible employment contracts and particularly the widespread use of temporary contracts tend to amplify reactions in the labour market to variations in aggregate demand in both directions. ${ }^{18}$ Thus, reductions in employment during a contraction of output are likely to be more severe in countries with weaker employment protection legislation. This affirmation has been amply verified during the current recession as is illustrated also by Table $2 .{ }^{19}$ The hopeful corollary that the recovery in output and employment will be quicker in flexible labour markets is much less obviously the case. Returning to the elasticity estimates produced by the rolling regressions, one would hope to observe the maintenance of a relatively substantial elasticity of youth employment with respect to both adult employment and GDP also during periods of expansion. However, examination of the elasticity estimates produced by the rolling regressions reveals that, for example, in the UK, for almost the entire period covered by the rolling regressions up until the onset of the recession, in other words during a period of output expansion in the UK, the elasticity of youth employment to GDP was actually negative. ${ }^{20}$ In contrast, in Germany the elasticity of youth employment with respect to adult employment during

example, O’Higgins (2008) for further discussion of some of behavioural implications of this in Italy, or OECD (2007) for an analysis of the situation in Spain.

${ }^{18}$ See, for example, IMF (2010). I have argued elsewhere that the evidence presented in support of this argument is, to say the least, rather weak (O'Higgins, 2010). A number of papers have looked at the direct effects of temporary employment at the individual level. See, for example, the collection of papers in the symposium in the Economic Journal, vol. 112, no. 480, 2002. Of the four substantive papers in the collection, three find negative effects of temporary employment (Blanchard and Landier, 2002; Booth et al., 2002 and Dolado et al., 2002) with only one (Holmlund and Storrie, 2002) suggesting a (partially) positive role. Although, the general picture has not changed subsequently, some analyses have found a positive role for temporary employment as a stepping-stone to permanent employment. For example, in their review of the literature, Zijl and Van Leeuwan (2005), report positive 'steppingstone' effect for temporary jobs in Germany, the Netherlands and Italy, but not for Spain. Zijl et al. (2011) analysing the situation in the Netherlands in more detail find that although temporary jobs do shorten unemployment durations, they do not lead to an increase in the likelihood of being in regular employment subsequently. In Italy several studies (for example, Ichino et al. (2005, 2008) and Barbieri \& Sestito (2008)) have found a weak positive effect of temporary employment on the chances of finding permanent employment, although Gagliarducci (2005) finds that the intermittence of work experience associated with temporary work tends to impede the transition to permanent employment and Berton et al. (2008) whilst noting that the probability of the transition to permanent employment is higher from temporary employment than unemployment, they also observe that the existence of strong state dependence or persistence in temporary employment; particularly, for young people, there is a tendency towards 'permanent precariousness' with new labour market entrants becoming trapped in repeated short-term contracts.

${ }^{19}$ See, amongst many others, O’Higgins (op.cit.).

${ }^{20}$ To be precise, the estimated elasticity of youth employment to GDP produced by the rolling regressions is negative in the UK for the regressions with end periods between 2003Q2 and 2009Q1 inclusive. 
the first five years of the new millennium, a period of moderate positive economic growth in Germany, remained above 3, reaching a peak of 3.6, or more than twice the end-period elasticity estimated during the current recession. Thus, in the UK the short-run elasticity of youth employment was negative so that youth and adult workers were effectively substitutes, not complements with more adult employment corresponded to less, not more, youth employment. In Germany, younger and prime-age workers were complements so that increases in adult employment were accompanied by increases in youth employment during a period of positive growth.

In any event, the rolling regressions allow a further understanding of some of the dynamic processes underlying the cross-country differences in the reactions of youth labour markets to the current recession. Differences observable across countries in the relationship between youth employment and unemployment on the one hand, and the severity of the recession on the other, are largely attributable to differences in the reactivity of youth employment to adult employment, which, in countries with flexible labour markets, tends to be substantial. Thus, for example, the explanation of why similar falls in GDP in Ireland (-12\%), Poland (-11\%) and Romania (-11\%) resulted in such differing falls in youth employment (-53\% in Ireland, - 16\% in Poland and $-9 \%$ in Romania) lies principally in the responsiveness of youth employment to adult employment, or, in other words, to aggregate labour demand. In turn, the explanation for differing elasticities of youthto-adult employment can largely be explained in terms of the institutional structure of youth labour markets and in particular, the relative ease with which temporary contracts allow adjustment at the margin through the hiring and firing of young workers. ${ }^{21}$

\section{Conclusions}

This paper has examined some of the key characteristics of the effects of the current Great Recession on the labour market experiences of young people in the EU. It was argued that young people were hit particularly hard by the recession. The key element of this argument was that the

\footnotetext{
${ }^{21}$ Based on the moving average of real GDP employed in the regression analysis reported in table 2.
} 
recession has seen an upsurge in the incidence of long-term unemployment amongst young people at a much faster rate than has occurred amongst prime-aged workers. Also of note, during the recession, the incidence of temporary employment amongst young workers has continued to rise, becoming the dominant form, in some countries almost the only form, of new employment contracts for young people.

This aspect is of some concern because the cross section and time series analyses both suggest that the youth employment loss arising from the recession was reduced in countries with stronger not weaker employment protection legislation. Moreover, the analysis of the countryspecific coefficients in the rolling regressions for the period prior to the recession further suggests that the strongly negative adjustment of youth employment in countries with relatively flexible labour markets prompted by the recession was not counterbalanced by a strong positive adjustment of youth employment to the growth in aggregate labour demand in the period of expansion prior to the downturn. This bodes ill for the future of youth employment growth if and when the 'Great Recovery' starts also in the light of the significant increases in the incidence of long-term unemployment which has accompanied this Great Recession. 


\section{References}

Barbieri, G. and Sestito, P. 2008: Temporary workers in Italy: Who are they and where they end up. Labour 22: 127-166.

Bassanini, A. and Duval, R. 2006: Employment patterns in OECD countries: Reassessing the role of policies and institutions. OECD Social, Employment and Migration Working papers no. 35.

Bertola, G., Blau, F.D. and Kahn, L.M. 2007: Labor market institutions and demographic employment patterns. Journal of Population Economics 20: 833-867.

Berton, F., Devicienti, F. and Pacelli, L. 2008: Temporary jobs: Port of entry, trap or unobserved heterogeneity? Laboratorio Riccardo Revelli Working Paper no. 79.

Blanchard, O. and Landier, A. 2002: The perverse effects of partial labour market reform: Fixedterm contracts in France. Economic Journal 112: F214-F244.

Booth, A.L., Francesconi, M. and Frank, J. 2002: Temporary jobs: Stepping stones or dead ends?

Economic Journal 112: F189-F213.

Cazes, S., Verick, S. and Al Hussami, F. 2011: Diverging trends in unemployment in the United States and Europe: Evidence from Okun's law and the global financial crisis. ILO Employment Working Paper no. 106.

Choudhry, M., Marelli, E. and Signorelli, M. 2012: Youth unemployment and the impact of financial crises. Forthcoming International Journal of Manpower 33.

Clark, K. B. and Summers, L. H. 1982: The dynamics of youth unemployment. NBER Working Paper Series no 0274.

Cockx, B. and Picchio, M. 2011: Scarring effects of remaining unemployed for long-term unemployed school-leavers. Institute de Recherches Économiques et Sociale de L'Université catholique de Louvain, Discussion Paper 2011-32.

Dolado, J.J., García-Serrano, C. and Jimeno, J.F. 2002: Drawing lessons from the boom of temporary jobs in Spain. Economic Journal 112: F270-F295

European Commission, 2009: Employment in Europe 2009. European Commission: Brussels.

European Commission, 2010: Employment in Europe 2009. European Commission: Brussels.

Gagliarducci, S. 2005: The dynamics of repeated temporary jobs. Labour Economics 12: 429-448.

Gregg, P. 2001: The impact of youth unemployment on adult unemployment in the NCDS.

Economic Journal : F626-E653.

Gregg, P. and Tominey, E. 2005: The wage scar from male youth unemployment. Labour Economics 12: 487-509.

Holmlund, B. and Storrie, D. 2002: Temporary work in turbulent times: The Swedish experience. Economic Journal 112: F245-F269. 
Ichino, A., Mealli, F. and Nannicini, T. 2005: Temporary work agencies in Italy: A springboard toward permanent employment? Giornale degli Economisti e Annali di Economia 64: 1-27.

Ichino, A., Mealli, F. and Nannicini, T. 2008: From temporary help jobs to permanent employment: What can we learn from matching estimators and their sensitivity? Journal of Applied Econometrics 23: 305-327.

IMF. 2009: World economic outlook: Crisis and recovery, IMF: Washington D.C..

IMF. 2010: World economic outlook: Rebalancing growth. IMF: Washington D.C..

Jimeno, J.F. and Rodriguez-Palenzuela, D. 2002: Youth unemployment in the OECD: Demographic shifts, labour market institutions, and macroeconomic shocks. ECB Working paper no. 155, June.

Korenman, S. and Neumark, D. 2000: Cohort crowding and youth labor markets: A cross-national analysis. in D. Blanchflower and R. B. Freeman (ed.s), Youth Employment and Joblessness in Advanced Countries. University of Chicago Press: Chicago.

O'Higgins, N. 1997: The challenge of youth unemployment. International Social Security Review 50: 63-93.

O'Higgins, N. 2001: Youth unemployment and employment policy: A global perspective. ILO: Geneva.

O'Higgins, N. 2008: Still with us after all of these years: Trends in youth labour market entry, home-leaving and human capital accumulation in Italy 1993-2003. in G. DeFreitas (ed.), Young Workers in the Global Economy: Job Issues in North America, Europe and Japan, Edward Elgar: Cheltenham.

O'Higgins, N. 2010: The impact of the economic and financial crisis on youth employment: Measures for labour market recovery in the European Union, Canada and the United States. ILO: Employment Working Paper No. 70.

O'Higgins, N. 2011: Italy: Limited policy responses and industrial relations in flux, leading to aggravated inequalities, in Vaughan-Whitehead (ed.) Inequalities in the world of work: The effects of the crisis. Edward Elgar: Cheltenham.

Rice, P. 1986: Juvenile unemployment, relative wages and social security in Great Britain. Economic Journal 96: 352-374.

Ryan, P. 2001: The school-to-work transition: A cross-national perspective. Journal of Economic Literature 39: 34-92.

Sachs, A. 2011: Institutions and unemployment: Do interactions matter? ZEW Discussion Paper no. 11-057.

Shimer, R. 2001: The impact of young workers on the aggregate labour market," Quarterly Journal of Economics 116: 969-1007. 
Scarpetta, S., Sonnet, A. and Manfredi, T. 2010: Rising youth unemployment during the crisis: How to prevent negative long-term consequences on a generation? OECD Social, Employment and Migration Working Papers No. 106.

Verick, S. 2009: Who is hit hardest during a financial crisis? The vulnerability of young men and women to unemployment in an economic downturn. IZA Discussion Paper no. 4359.

Zijl, M., Van den Berg, G. J. and Heyma, A. 2011: Stepping stones for the unemployed: the effect of temporary jobs on the duration until (regular) work. Journal of Population Economics 24: 107139.

Zijl, M.; Van Leeuwan, M. 2005: Temporary jobs: Intermediate positions or jumping boards, SEO Discussion paper no. 38. 